\title{
An Impact of Education Marketing on Enrolment of Students at Private Management Colleges in Kathmandu
}

\author{
Sagar Pokhrel ${ }^{3}$, Ashish Tiwari ${ }^{4}$ and Ram Kumar Phuyal ${ }^{5}$
}

\begin{abstract}
:
This paper attempts to examine the impact of different educational marketing activities undertaken by Kathmandu valley located selected private management colleges. The study has gone through the behaviour of BBA and MBA enrolled students who were recruited by the private management colleges (affiliated to both domestic and foreign universities in Nepal). The conceptual model adopted for this study consists with 7Ps of marketing mix developed by Kotler and Fox (1995) which is specially designed for educational institutions. Selfadministered questionnaires were distributed to 342 students studying in 9 different colleges of Kathmandu valley in the year 2015, and the collected data was analyzed through descriptive statistics approaches. The analysis of the available information revealed that the most important influencing factor for admission at the BBA and MBA levels was recommendations made by the friends. However, the words of mouth i.e. family and relatives' recommendations, colleges' website and newspapers' advertisements were also found to be effective. At the BBA level, lecturers, provision for extra-curricular activities, library and IT facilities were also of the high value for the enrolment whereas at the MBA level, profile of lecturers, teaching practices, possibilities of future employment opportunities and better placement were high on the agenda. We believe that the outcome of this study will be helpful for all private colleges, advertising agencies, and government educational agencies of Nepal to understand the psychology of students and to develop effective marketing strategies. It will further support to regulate those activities that best meet the interest of students and service providers to increase attraction among all the potential students in the private colleges.
\end{abstract}

Key-words: 7Ps of marketing, descriptive statistics, primary survey, private management colleges and Kathmandu valley.

JEL-Codes: M21, M31 and M37

3 Mr. Pokhrel is faculty inLaligurans Rastriya College, Kathmandu

4 Mr. Tiwari is Principal/Director of Ace Institute of Management (AIM), Pokhara University.

5 Dr. Phuyal is Associate Professor in CEDA, Tribhuvan University

Corresponding email:sagar.inform@gmail.com 


\section{Introduction}

Throughout the world, higher education plays significant role in any nation's development. It not only provides qualified human resources but also increases social, political and cultural awareness. Highly educated citizens make significant contribution in improving the living standard and overall productivity of the society. To achieve desired social and economic growth many countries in the world are making significant investment to introduce and upgrade their education system.

The Nepalese Government is also investing heavily on education for social and economical development of the country. However, in under developed countries like Nepal, it is difficult for the government to provide higher education single handily. This has lead to the private participation in offering higher education. These private education service providers come into the picture with the aim of making profits and fulfilling the social responsibilities. As the need of the students and demand of market is varied, private colleges have introduced different courses affiliated to both domestic and foreign universities.

Kathmandu, being the capital of Nepal, most of the educational and economical activities are centred here. This has increased the flow of students to Kathmandu as the city offers more opportunities for higher education and personal development. Realizing the huge potential of growth and economic benefit in the education sector, the number of private colleges has significantly increased in the valley. There are around 65 private colleges in Kathmandu valley which offers BBA degree affiliated to different universities. Similarly there are around 27 MBA private colleges in Kathmandu valley. This has increased the competition among the private colleges to attract more students. They, therefore, adopt extensive marketing strategies to promote their college. They strategically link the 7Ps of service marketing to enhance the possibility of private colleges to meet the needs and wants of the students. Private colleges are making huge investment in formulating and implementing marketing strategies to increase enrolment in their college.

Hence, this study makes an attempt to analyze the effect of marketing efforts of the private colleges from the students' perspective focusing on activities of the private college operating in Kathmandu. For the research, recently enrolled students in BBA and MBA program were surveyed as they have high chances of recalling the decisions made during the enrolment process. The major objectives of this research are as follows: 
- To identify how students at BBA and MBA level studying in different private management colleges value the different factors while selecting the college.

- To examine the association of promotional activities of private management colleges with that of enrolment in BBA and MBA level.

\section{Review of Literature}

Bulley (2014) highlighted the existence of strategic marketing planning for private tertiary institutions. As to the marketing mix variables application, it was realized that not all 7p's are used in sync and this has an impact on the institution's performance. The research findings indicate that long term and short term plan are used and a marketing plan drives the institutions' activities. Bamfa (2013) investigated the role of marketing communications in the enrolment of students in private universities in Ghana. It was found that private universities that effectively and efficiently manage their advertising campaigns stand the chance of positioning themselves well and thus gain sustainable competitive advantage in the industry. Chawla (2013) also emphasized the existence of 7 Ps of service marketing mix in education service sector, which have their significance for the students, while making their choice about any institution. Odio(2014) conducted a research about factors influencing students' enrolment in social studies education and found that employment opportunities, gender and environment factors influence students' enrolment in social studies programmes. Fosu(2014) made an attempt to identify the important factors that influence students' choice of university. The study found that, courses offered, high calibre lecturers, well stocked library and internet, flexible lecture time table, and recognition of qualification by employers were the most important factors that influence students' choice of university.

Yamamoto (2006) examined the university selection criteria of students for better university management with the use of marketing tools and found that families were very influential when one is selecting a university. Haur (2009) conducted a research to determine and understand the factors influencing students' intention to continue their study at higher educational institutions. The study found that cost of education, content and structure of degree, people (family, friends, peers, and teachers), gender and educational background are significant factors that influence student's intention to study at a higher education institution. Messah (2011) conducted a study on student enrolment in private universities in Kenya and revealed that print media; newspapers, brochures and alumni networks were rated highly as the most effective marketing communication tools to provide information to prospective students. Similarly, Sarwar (2012) examined the factors that influence the students in selecting their higher learning programs in various higher 
learning institutions in Malaysia. The result shows that university teaching quality is the most important factor that influences a student in selection of his/her higher learning institution followed by university facilities, program structure and accreditation, campus facilities. Sia (2013), aimed at finding out the factors students consider important in their college choice decision and to provide marketing implications for educational administrators. Results suggested that prospective students consider programme, cost (financial aid), location, high school personnel, peers and friends and campus visit as important criteria in their college choice decision.

In another study, Ho (2008) revealed that the five most important factors for students' school selection were: employability, curriculum, academic reputation, faculty, and research environment. Mehboob (2012) explored those factors that stand out critically in influencing and determining student's attendance decision in HEI's. The factor "facility" is the most influential attribute found in determining student enrolment decisions in HEI's. Lai (2014) conducted a study to address the general problem at the college level and related it to the trends at the university and at the national level. Secondary school guidance counsellors, followed by current and previous college students were the highlights in order of magnitude for nonmarketing information sources for college choice. Social life received the highest loadings among college attributes and phone calls from the admissions office received the highest loading among marketer-controlled variables.

A study was also conducted adopting students as customer approach. Watjatrakul (2014) examined students' beliefs regarding outcomes of the adoption of the student-as-customer concept and the interaction effects of these outcomes and the social influence on students' attitudes toward acceptance of the student-ascustomer concept and their intentions to study at universities. The result indicated that students believe that the universities' adoption of the students as customer concept will lead to improvement of the educational service. The instructors are more committed to increase educational quality and pairing student-instructor relationship. This will help in achieving course achievement easily

Most of the researches have accepted the need for strategic marketing planning in promoting the educational services. The impact of different marketing variables is also studied to identify key factors that affect the enrolment in higher education. Efforts have also been made to identify new marketing mix that is more suitable to promote educational services. Among the outcomes of the researches most of the students prefer qualified lecturers. College facilities, and employment opportunities were the other factors students valued more while selecting a college. 
However, it should be noted that the student behaviour differs in terms of geographical, cultural, economical and educational needs. The variables of 7Ps selected for the research are also determined on the basis of use in the promotional activities. So, this research attempts to analyze the marketing activities performed by private management colleges of Kathmandu on the basis of the promotional factors used by them during enrolment. Based on this, the research attempts to answer following questions:

- What factors students value most in selecting private management college for higher education?

- How can private management colleges increase effectiveness of their marketing approaches to increase attraction and enrolment?

\section{The Methodology}

The respondents of the research are the students who were recently enrolled at BBA and MBA level at private colleges in Kathmandu in 2015. The source of data is primary. Self-administered questionnaire was distributed to the students. Pilot survey was conducted among 15 students to check the reliability of the questionnaire and collected data. The target population composed of students studying BBA and MBA in 73 private colleges in Kathmandu valley, which total to 5000.Non probability convenience sample technique, was used to select the respondents for the research. Response of 342 students studying in 9 different private management colleges was recorded and analyzed using SPSS and MS Excel. The sample size is about $7 \%$ of the total population. The data collected from the survey was first coded into appropriate categories in SPSS. The Pearson Chisquare was used to test the level of significance of the factors of 7Ps that influence the enrolment at BBA and MBA level.

The conceptual framework for the research consist of 7Ps of marketing mix developed by Kotler and Fox (1995) which is specially designed for educational institutions. 


\begin{tabular}{|c|c|}
\hline $\begin{array}{l}\qquad \text { Product } \\
\text { University affiliation } \\
\text { Employment opportunities of the of the course } \\
\text { Previous academic results and students } \\
\text { performance } \\
\text { Placement offered by the college }\end{array}$ & \\
\hline $\begin{array}{l}\text { Price } \\
\text { Program fee } \\
\text { Discounts and scholarships }\end{array}$ & \\
\hline $\begin{array}{ll} & \text { Promotion } \\
\text { Newspaper } & \text { Magazines } \\
\text { Television } & \text { Friends } \\
\text { Radio } & \text { Family/relatives } \\
\text { Facebook Already } & \text { enrolled students } \\
\text { Websites } & \text { Educational events } \\
\text { Hoarding Boards } & \end{array}$ & \\
\hline $\begin{array}{l}\text { Place } \\
\text { College location and accessibility }\end{array}$ & $\begin{array}{l}\text { Student Enrollment } \\
\text { (BBA / MBA Level) }\end{array}$ \\
\hline $\begin{array}{l}\text { People } \\
\text { Lecturers } \\
\text { Management team }\end{array}$ & \\
\hline $\begin{array}{l}\qquad \text { Process } \\
\text { Teaching practices } \\
\text { Provision for extra-curricular activities }\end{array}$ & \\
\hline $\begin{array}{l}\qquad \text { Physical Evidence } \\
\text { Building attractiveness and classroom layout } \\
\text { Library and IT facilities } \\
\text { Sufficient playing arena } \\
\text { Cafeteria }\end{array}$ & \\
\hline
\end{tabular}

Figure 1: Conceptual framework 
The 7Ps of service marketing i.e. Product, Price, Promotion, People, Place, Process and Physical evidence are taken as independent variables, whereas, student enrolment at BBA/MBA level is taken as dependent variable. Different factors are studied under each independent variable to make the results more specific and effective. Students were asked to respond to 11 promotional media the colleges were using, to analyze the effectiveness of each of them in the enrolment process. To identity what students' value most during enrolment, the students were also asked to respond to 15 factors based on the extent of importance of each factor when taking a decision to enrol in the particular college. The factors are determined on the basis of involvement of those factors in promotional activities of the private colleges.

\section{Result and Discussion}

Out of total 342 respondents 206 were studying BBA and 136 were studying MBA. The respondents at BBA level consist of 103 male and 103 female. The number of male and female respondents studying MBA was 74 and 62. Majority of the respondents in this research enrolled in BBA and MBA were from management background constituting about $82 \%$ in BBA and about $95 \%$ in MBA. It's noteworthy that about $17 \%$ respondents who enrolled in BBA were from science background.

Among the respondents studying BBA, majority of the respondents (64\%) claimed that they knew the college they were currently studying few months before admission. Whereas at MBA level, it was found that majority of the respondents (39\%) had known the college for more than 2 years. Also, about $28 \%$ respondents at MBA level claimed that they knew the college few months before admission. After analyzing the response it was revealed that both at the BBA and MBA level majority of the students knew about the college from their friends. It was found that significant number of students knew about the college they are currently studying from relatives/friends. Promoting the college through different websites was also found effective. However, Radio, TV and Magazines were among the least effective medium to know about the college as shown in Table 1.

The study also highlighted the behaviour of respondents regarding visiting college website. About $62 \%$ respondents at BBA level visited the college website before joining and $51 \%$ of them agree that college website correctly represent the college. Similarly about $76 \%$ of respondent at MBA level visited the college website before joining and $54 \%$ of them agree that college website correctly represent the college. It was also found that about $29 \%$ respondent of BBA level knew about the admission open in the college they are currently studying through college website, whereas about $35 \%$ respondents of MBA level knew about the admission open 
through college website. This indicates that proper and updated information in the college website can positively influence the enrolment at both BBA and MBA level. Similarly, newspaper advertisements were found more effective in enrolment at MBA level. About $48 \%$ of the respondents knew about the admission open in the college they are currently studying through newspaper advertisements.

Table 1: Ranking of medium of information about the college

\begin{tabular}{|c|c|c|c|c|c|}
\hline \multirow{2}{*}{$\begin{array}{l}\text { Knew about the } \\
\text { college through }\end{array}$} & $\begin{array}{l}\text { Education } \\
\text { level }\end{array}$ & \multirow[t]{2}{*}{ Rank } & \multirow{2}{*}{$\begin{array}{l}\text { Knew about } \\
\text { the college } \\
\text { through }\end{array}$} & \multirow{2}{*}{$\begin{array}{l}\begin{array}{l}\text { Education } \\
\text { level }\end{array} \\
\text { MBA }\end{array}$} & \multirow[t]{2}{*}{ Rank } \\
\hline & BBA & & & & \\
\hline Friends & $45.60 \%$ & 1 & Friends & $69.10 \%$ & 1 \\
\hline Family / relatives & $44.70 \%$ & 2 & Newspaper & $41.20 \%$ & 2 \\
\hline Different websites & $23.80 \%$ & 3 & $\begin{array}{l}\text { Family / } \\
\text { relatives }\end{array}$ & $30.90 \%$ & 3 \\
\hline Newspaper & $16.50 \%$ & 4 & $\begin{array}{l}\text { Already } \\
\text { enrolled } \\
\text { students }\end{array}$ & $29.40 \%$ & 4 \\
\hline Facebook & $15.00 \%$ & 5 & $\begin{array}{l}\text { Different } \\
\text { websites }\end{array}$ & $25.70 \%$ & 5 \\
\hline $\begin{array}{c}\text { Already enrolled } \\
\text { students }\end{array}$ & $14.10 \%$ & 6 & $\begin{array}{c}\text { Educational } \\
\text { events }\end{array}$ & $17.60 \%$ & 6 \\
\hline Educational events & $10.20 \%$ & 7 & Facebook & $16.90 \%$ & 7 \\
\hline Hoarding Boards & $8.70 \%$ & 8 & $\begin{array}{l}\text { Hoarding } \\
\text { Boards }\end{array}$ & $16.20 \%$ & 8 \\
\hline TV & $4.90 \%$ & 9 & Magazines & $10.30 \%$ & 9 \\
\hline Magazines & $4.40 \%$ & 10 & TV & $7.40 \%$ & 10 \\
\hline Radio & $0.50 \%$ & 11 & Radio & $1.50 \%$ & 11 \\
\hline
\end{tabular}

On the other hand, lecturers, provision for extra-curricular activities and library and IT facilities were highly valued by respondents of BBA level during enrolment. At MBA level, lecturers, teaching practices and employment opportunities were highly valued by the respondents during enrolment. During enrolment students at MBA level were more concerned about the program fee, whereas, students at BBA level were interested in the discount and scholarships available in the college. Students at MBA level were least concerned with the availability of sufficient playing arena in the college.

Table 2 and Table 3 show the ranking of different factors valued by the respondents of BBA and MBA level during the enrolment process. 
Table 2: Ranking of factors - BBA level

\begin{tabular}{|c|c|c|c|c|c|c|}
\hline \multirow{2}{*}{ Factors } & \multicolumn{6}{|c|}{ Education level - BBA } \\
\hline & $\begin{array}{c}\text { Very } \\
\text { Important }\end{array}$ & Important & $\begin{array}{c}\text { Less } \\
\text { Important }\end{array}$ & $\begin{array}{c}\text { Not } \\
\text { Important }\end{array}$ & Total & Rank \\
\hline Lecturers & $57.30 \%$ & $40.80 \%$ & $1.90 \%$ & $0.00 \%$ & $98.10 \%$ & 1 \\
\hline $\begin{array}{l}\text { Provision for } \\
\text { extra- curricular } \\
\text { activities }\end{array}$ & $52.90 \%$ & $44.70 \%$ & $1.50 \%$ & $1.00 \%$ & $97.60 \%$ & 2 \\
\hline $\begin{array}{l}\text { Library and IT } \\
\text { facilities }\end{array}$ & $53.90 \%$ & $43.20 \%$ & $2.40 \%$ & $0.50 \%$ & $97.10 \%$ & 3 \\
\hline $\begin{array}{l}\text { Teaching } \\
\text { practices }\end{array}$ & $64.60 \%$ & $32.00 \%$ & $3.40 \%$ & $0.00 \%$ & $96.60 \%$ & 4 \\
\hline $\begin{array}{l}\text { Employment } \\
\text { opportunities of } \\
\text { the course }\end{array}$ & $57.80 \%$ & $38.80 \%$ & $2.90 \%$ & $0.50 \%$ & $96.60 \%$ & 4 \\
\hline $\begin{array}{l}\text { Placement } \\
\text { offered by the } \\
\text { college }\end{array}$ & $55.30 \%$ & $41.30 \%$ & $2.90 \%$ & $0.50 \%$ & $96.60 \%$ & 4 \\
\hline $\begin{array}{l}\text { Management } \\
\text { team }\end{array}$ & $59.20 \%$ & $36.40 \%$ & $3.40 \%$ & $1.00 \%$ & $95.60 \%$ & 5 \\
\hline $\begin{array}{l}\text { Discounts and } \\
\text { scholarships }\end{array}$ & $64.60 \%$ & $30.60 \%$ & $3.90 \%$ & $1.00 \%$ & $95.20 \%$ & 6 \\
\hline $\begin{array}{l}\text { Previous } \\
\text { academic results } \\
\text { of the college }\end{array}$ & $44.70 \%$ & $47.60 \%$ & $5.30 \%$ & $2.40 \%$ & $92.30 \%$ & 7 \\
\hline $\begin{array}{l}\text { University } \\
\text { affiliation }\end{array}$ & $55.30 \%$ & $33.50 \%$ & $6.80 \%$ & $4.40 \%$ & $88.80 \%$ & 8 \\
\hline $\begin{array}{l}\text { College location } \\
\text { and accessibility }\end{array}$ & $31.10 \%$ & $53.40 \%$ & $13.60 \%$ & $1.90 \%$ & $84.50 \%$ & 9 \\
\hline Cafeteria & $33.00 \%$ & $49.00 \%$ & $17.00 \%$ & $1.00 \%$ & $82.00 \%$ & 10 \\
\hline $\begin{array}{l}\text { Sufficient } \\
\text { playing arena }\end{array}$ & $27.20 \%$ & $51.50 \%$ & $18.90 \%$ & $2.40 \%$ & $78.70 \%$ & 11 \\
\hline $\begin{array}{l}\text { Building } \\
\text { attractiveness \& } \\
\text { classroom layout }\end{array}$ & $23.80 \%$ & $52.90 \%$ & $20.90 \%$ & $2.40 \%$ & $76.70 \%$ & 12 \\
\hline Program fee & $32.00 \%$ & $42.20 \%$ & $21.80 \%$ & $3.90 \%$ & $74.20 \%$ & 13 \\
\hline
\end{tabular}


Table 3: Ranking of factors - MBA level

\begin{tabular}{|c|c|c|c|c|c|c|}
\hline \multirow[b]{2}{*}{ Factors } & \multicolumn{6}{|c|}{ Education level - MBA } \\
\hline & $\begin{array}{c}\text { Very } \\
\text { Important }\end{array}$ & Important & $\begin{array}{c}\text { Less } \\
\text { Important } \\
\end{array}$ & $\begin{array}{c}\text { Not } \\
\text { Important }\end{array}$ & Total & Rank \\
\hline Lecturers & $76.50 \%$ & $23.50 \%$ & $0.00 \%$ & $0.00 \%$ & $\begin{array}{r}100.00 \\
\%\end{array}$ & 1 \\
\hline Teaching practices & $74.30 \%$ & $25.00 \%$ & $0.70 \%$ & $0.00 \%$ & $99.30 \%$ & 2 \\
\hline Employment opportunities of the course & $61.00 \%$ & $38.20 \%$ & $0.70 \%$ & $0.00 \%$ & $99.20 \%$ & 3 \\
\hline Management team & $69.90 \%$ & $28.70 \%$ & $1.50 \%$ & $0.00 \%$ & $98.60 \%$ & 4 \\
\hline Placement offered by the college & $64.00 \%$ & $31.60 \%$ & $4.40 \%$ & $0.00 \%$ & $95.60 \%$ & 5 \\
\hline Library and IT facilities & $55.10 \%$ & $39.70 \%$ & $5.10 \%$ & $0.00 \%$ & $94.80 \%$ & 6 \\
\hline Program fee & $52.20 \%$ & $40.40 \%$ & $6.60 \%$ & $0.70 \%$ & $92.60 \%$ & 7 \\
\hline $\begin{array}{l}\text { Previous academic results of the college } \\
\text { and students performance }\end{array}$ & $52.90 \%$ & $39.00 \%$ & $8.10 \%$ & $0.00 \%$ & $91.90 \%$ & 8 \\
\hline University affiliation & $51.50 \%$ & $39.70 \%$ & $8.10 \%$ & $0.70 \%$ & $91.20 \%$ & 9 \\
\hline Provision for extra- curricular activities & $41.20 \%$ & $44.10 \%$ & $14.00 \%$ & $0.70 \%$ & $85.30 \%$ & 10 \\
\hline Discounts and scholarships & $45.60 \%$ & $39.00 \%$ & $12.50 \%$ & $2.90 \%$ & $84.60 \%$ & 11 \\
\hline College location and accessibility & $29.40 \%$ & $55.10 \%$ & $15.40 \%$ & $0.00 \%$ & $84.50 \%$ & 12 \\
\hline $\begin{array}{l}\text { Building attractiveness and classroom } \\
\text { layout }\end{array}$ & $17.60 \%$ & $66.20 \%$ & $15.40 \%$ & $0.70 \%$ & $83.80 \%$ & 13 \\
\hline Cafeteria & $23.50 \%$ & $52.90 \%$ & $22.10 \%$ & $1.50 \%$ & $76.40 \%$ & 14 \\
\hline Sufficient playing arena & $15.40 \%$ & $44.10 \%$ & $34.60 \%$ & $5.90 \%$ & $59.50 \%$ & 15 \\
\hline
\end{tabular}

\section{1 Hypothesis testing}

In this research Chi Square test is done to study how significantly student enrolment at BBA and MBA level is associated with 7Ps of education marketing. The result of Chi Square test shows how similarly or differently BBA and MBA level students respond to different factors adopted by private colleges for promotional activities. Table 4 shows the acceptance and rejection of hypothesis established for the research.

Table 4 Hypothesis Testing

\begin{tabular}{|l|l|c|c|l|}
\hline Hypothesis & Statement & $\begin{array}{c}\text { Chi- } \\
\text { Square } \\
\text { value }\end{array}$ & $\begin{array}{c}\text { Sig } \\
\text { value }\end{array}$ & Remarks \\
\hline $\mathrm{H}_{1}$ & $\begin{array}{l}\text { There is no significant } \\
\text { relationship between education } \\
\text { level and student knowing } \\
\text { about admission open through } \\
\text { newspaper advertisements. }\end{array}$ & 53.714 & 0.000 & Rejected \\
\hline $\mathrm{H}_{2}$ & $\begin{array}{l}\text { There is no significant } \\
\text { relationship between education } \\
\text { level and university affiliation } \\
\text { while selecting the college. }\end{array}$ & 4.993 & 0.172 & Accepted \\
\hline
\end{tabular}




\begin{tabular}{|l|l|l|l|l|}
\hline $\mathrm{H}_{3}$ & $\begin{array}{l}\text { There is no significant } \\
\text { relationship between education } \\
\text { level and discounts \& } \\
\text { scholarships while selecting } \\
\text { the college. }\end{array}$ & 17.005 & 0.001 & Rejected \\
\hline $\mathrm{H}_{4}$ & $\begin{array}{l}\text { There is no significant } \\
\text { relationship between education } \\
\text { level college location \& } \\
\text { accessibility while selecting } \\
\text { the college. }\end{array}$ & 2.956 & 0.398 & Accepted \\
\hline $\mathrm{H}_{5}$ & $\begin{array}{l}\text { There is no significant } \\
\text { relationship between education } \\
\text { level and lecturers while } \\
\text { selecting the college. }\end{array}$ & 14.472 & 0.001 & Rejected \\
\hline $\mathrm{H} 0_{6}$ & $\begin{array}{l}\text { There is no significant } \\
\text { relationship between education } \\
\text { level and teaching practices } \\
\text { while selecting the college. }\end{array}$ & 4.998 & 0.082 & Accepted \\
\hline $\mathrm{H}_{7}$ & $\begin{array}{l}\text { There is no significant } \\
\text { relationship between education } \\
\text { level and building } \\
\text { attractiveness \& classroom } \\
\text { layout while selecting the } \\
\text { college. }\end{array}$ & 6.552 & 0.088 & Accepted \\
\hline
\end{tabular}

\section{Conclusion}

The findings show that recommendations from friends, family and relatives were among the most effective medium to communicate about the colleges at both BBA and MBA level. However, at the MBA level newspaper advertisements significantly influenced the enrolment. Students also relied heavily on getting college updates from the college website; as majority of the respondents at both BBA and MBA level believe that college website correctly represent the college. Significant number of respondents at both BBA and MBA level knew about the admission open in the college through college website. This indicates that college websites updated with relevant information and different activities of the college can positively influence the enrolment at both levels.

The findings of this paper indicate that most of the factors are equally valued by the students at both BBA and MBA level. Factors such as lecturers, employment opportunities of the course, placement offered by the college, teaching practices were highly valued by students at both BBA and MBA level. It was also found that 
there are some factors which can significantly influence enrolment at BBA and MBA level. Factors such as lecturers involved in the college and program fee were given more importance by MBA students than at BBA level. Similarly factors such as discounts and scholarships, provision for extra - curricular activities and sufficient playing arena were given more importance by BBA students than the MBA students.

However, all private colleges should consider this fact very seriously that all the 7Ps of education marketing are closely interlinked. Emphasizing on only few variables and factors will not ensure effectiveness in terms of student enrolment. Students may consider many factors as the fundamental requirements in a college. As in the study, some factors like cafeteria, location, accessibility, building attractiveness and classroom layout were considered less important by the respondents at both BBA and MBA level.

The study successfully accomplished its objectives. The study revealed how different factors of education marketing are valued by the students at BBA and MBA level during enrolment. Private colleges can develop effective short term and long term marketing plans to increase attraction and enrolment based on the outcome of this research. Colleges offering BBA program can effectively use personal recommendations such as friends/families referral to increase enrolment. For this the college should have the recruitment team which can provide relevant information about the college effectively to the prospective students and are helpful during the enrolment process. They should be able to communicate the key factors such as lecturers, discount and scholarships, library and IT facilities which students value most in selecting the college. Similarly college offering MBA degree can promote their program effectively through newspaper advertisements. The college can make smart investment to provide exposure and productivity of the students to increase employment opportunities which are highly valued by both BBA and MBA students while selecting the college. The outcome of this research will also be highly beneficial to the organizations and people involved in promotion, regulation and research for the development of higher education services. This research will be helpful in determining the requirements that satisfies students' expectation. 


\section{REFERENCES}

Alipour, M., Aghamohammadi, A., Ahmadi, R., \&Hadi, S. (2012).A new educational marketing mix: The $6 \mathrm{ps}$ for private school marketing in Iran. Research Journal of Applied Sciences, Engineering and Technology, Vol.4(21), 4314-4319.

Bamfo, B.A., \&Atara, B.A. (2013). The role of marketing communications in student

enrolment in private universities in Ghana. Global Advanced Research Journal of Management and Business Studies, Vol. 2(5), 268-278.

Bulley, C.A.(2014). Strategic marketing in education services, the case of private tertiary institution in Ghana. International Journal of Economics, Commerce and Management, Vol. II(6),1-17

Bunnell, T. (2005). Strategic marketing planning in international schools.International Journal of Educational Management, Vol. 19 (1), 5966.

Chawla, M. (2013).Customers' (Students') perception about 7Ps of higher education marketing mix.Asian Journal of Multidisciplinary Studies, Vol.1 (2), 106-112.

Enache, I.C. (2011). Marketing higher education using the 7 Ps framework. Bulletin of the Transylvania University of Brasov, Vol. 4(1), 23-30.

Fosu, F.F.,\&Poku, K. (2014).Exploring the Factors That Influence Students' Choice of Higher Education in Ghana, European Journal of Business and Management, Vol.6 (28), 209-220.

Haur, L.S. (2009). Higher education marketing concerns: Factors influencing Malaysian students' intention to study at Higher Education Institutions. Thesis submitted to University of Malaya, Malaysia.

Helgesen, O. (2008). Marketing for higher education: A relationship marketing approach. Journal of Marketing for Higher Education, Vol. 18 (1), 50-78.

Ho, H.F., \& Hung, C.C. (2008). Marketing mix formulation for higher education: An integrated analysis employing analytic hierarchy process, cluster analysis and correspondence analysis. International Journal of Educational Management, Vol. 22(4), 328 - 340.

Ivy, J. (2008). A new higher education marketing mix: The 7Ps for MBA marketing. International Journal of Educational Management, Vol. 22(4), 288-299. 
Kallio, R.E. (1995). Factors influencing the college choice decisions of graduate students.Research in Higher Education, Vol. 36 (1), 109-124.

Karcher, B.X. (2011). Recruiting for Higher Education: The Roles that Print, Web, and Social Media Play in the Decision Process for Prospective Students, Unpublished Master of Science thesis submitted to Department of Computer Graphics Technology,Purdue University, Indiana.

Khan, S.N., \&Qureshi, I.M. (2010). Impact of promotion on students' enrollment: A case of private schools in Pakistan.International Journal of Marketing Studies, Vol. 2(2), 267-274.

Kotler, P, \& Fox, K. A. (1995). Strategic Marketing for Educational Institutions, Prentice-Hall, New York, NY.

Lai, A.P.C., Gibson, P., \&Muthaly, S. (2014). Becoming an education provider of choice in Hong Kong: An inquiry into student decision making. International Journal of Educational Management, Vol. 28 (5), 590 - 609.

Maringe, F. (2006). University and course choice: Implications for positioning, recruitment and marketing. International Journal of Educational Management, Vol. 20 (6), 466 - 479.

Mehboob,F., Shah, S.M. M., \& Bhutto, N.A. (2012). Factors influencing student's enrollment decisions in selection of higher education institutions (HEI's).Interdisciplinary Journal of Contemporary Research in Business, Vol.4(5), 558-568.

Messah, O.B., \& Immaculate, M.N. (2011). Effect of selected marketing communication tools on student enrolment in private universities in Kenya. European Journal of Business and Management, Vol.3 (3), 172-205.

Ming, J.S.K. (2010). Institutional Factors Influencing Students' College Choice Decision in Malaysia: A Conceptual Framework.International Journal of Business and Social Science, Vol.1 (3), 53-58.

Moogan, Y.J. (2011). Can a higher education institution's marketing strategy improve the student-institution match? International Journal of Educational Management, Vol. 25 (6), 570 - 589.

Nguyen, N., \& LeBlanc, G. (2001). Image and reputation of higher education institutions in students' retention decisions.International Journal of Educational Management, Vol. 15 (6), 303 - 311. 
Odia, A.A.(2014).A Study of Factors Influencing Students' Enrolment in Social Studies Education at the Post-Secondary School Level in Nigeria.Asian Journal of Management Sciences \& Education.Vol. 3(2), 116-124.

Sarwar, A., Haque, A., \&Yasmin, F. (2012). Measuring students' perception towards university selection: An empirical investigation on Malaysian Post Graduate students. International Journal of Research in Commerce, Economics \& Management, Vol.2 (9), 13-20.

Sia, J.K.M. (2013).University Choice: Implications for Marketing and Positioning. Scientific \& Academic Publishing, Vol. 3(1), 7-14.

Soedijati, E.K., \&Pratminingsih, S.A. (2012).The impacts of marketing mix on students choice of university study case of private university in Bandung, Indonesia, presented on $2^{\text {nd }}$ International Conference on Business and Economic Research.

Starck, K., \&Zadeh, S.H. (2013). Marketing Within Higher Education Institutions A Case Study of Two Private Thai Universities. Unpublished MBA Thesis submitted to The School of Business, Science and Engineering,Mälardalen University, Sweden.

Watjatrakul, B. (2014). Factors affecting students' intentions to study at universities adopting the "student-as-customer" concept.International Journal of Educational Management, Vol. 28(6), 676 - 693.

Yamamoto, G.T. (2006). University evaluation-selection: a Turkish case. International Journal of Educational Management, Vol. 20 (7), 559 - 569. 